\title{
Improving Skill of Narrative Writing Thematically with Problem-Based Learning Based on Mind Mapping
}

\author{
Eli Nurliza $^{1^{*}}$, Cut Nurul Fahmi ${ }^{2}$, Rifaatul Mahmuzah ${ }^{3}$ \\ ${ }^{1,2,3}$ Faculty of Teacher Training and Education, Universitas Serambi Mekkah, Aceh, Indonesia \\ *Corresponding Author: eli.nurliza@serambimekkah.ac.id
}

\begin{abstract}
The purpose of this study is to describe the learning outcomes using a mind mapping-based problem-based learning model to improve the ability to write narratives thematically with SPSS for Windows Version of the Standard 16.0 to find the N-gain value, normality of data distribution, test data homogeneity, and test research hypotheses. The normality test of the initial test of the two classes was normally distributed. The results of the homogeneity test of the initial test of the two classes were homogeneously distributed with sig. $=0.491>0.05$, the average similarity test obtained a sig value of $(2$-tailed $)=0.538>0.05$, which means that there is no differences before treatment, the test of the difference in the average $N$-gain of all students (control class with experimental class) obtained the Asymp Value. Sig. (2-tailed) $=0.000$, so Sig. (1-tailed) $=0.000 / / 2$ $=0.001 .0 .001<0.05$. So it can be concluded that students skill to write narratives thematically who received learning using the problem base learning method based on mind mapping was better than students who received conventional narrative learning as a whole.
\end{abstract}

Keywords: Writing, method learning, thematic analysis

\section{Introduction}

Writing skill is an important aspect in the communication process. Writing is a benchmark for assessing the progress of a country (Tarigan, 2013). Writing is the last skill that is difficult to master after listening, reading, and speaking skills. Data from the National Center for Education Statistics (NCES) in 2012 shows that the writing skills of elementary school students to college students are very low due to the lack of creativity which causes high levels of plagiarism (Cahyani, Isah et al, 2019 Even though writing ability is one of the initial literacy that must be possessed by every individual to live in the 4.0 industrial revolution era. Given that new literacy includes data literacy, technological literacy, and human literacy. The importance of writing since elementary school is also emphasized in the 2013 curriculum by containing the fourth core standard, namely presenting factual knowledge in clear language, systematic and logical, in an aesthetic work (Mulyasa, 2013) Systematic and logical which is the hallmark of writing narratives.

According to Rusman (2012: 254-255), thematic is a learning model which in its implementation starts from a theme that is selected and developed by the teacher and students by paying attention to its relationship with the learning content. The purpose of this theme is not only to master the concepts in a subject, but also its relation to concepts from other subjects. "The determination of the theme starts from the closest environment and is recognized by students" (Rusman, 2012: p. 262). Rusman's opinion shows that the surrounding environment can encourage students to recognize everything that happens in the environment and explore to bring students closer to global knowledge about the environment. It can stimulate students' curiosity through questions, considerations and various environmental explorations towards global knowledge. The nature of environmental-based education encourages students to react using their abilities from various fields. Therefore, 
themes which are close to students' lives such as environmental themes are suitable for the early stages of developing writing skills.

The importance of thematic learning is applied in elementary schools because in general students at this stage still see everything as a whole (holistic), their physical development can never be separated from mental, social, and emotional development. By using the problembased learning method based on mind mapping, it is expected to be able to improve students' ability to write narratives thematically or holistically, so that learning to write narratives is not done partially.

\section{Method}

This research was conducted using an experimental method with a quantitative approach. There are two sample groups, namely the experimental group which is given treatment in the form of learning that applies the PBL (problem-based learning) model with mind mapping and the control group which uses the conventional model that is usually done. Both groups were given a pre-test and a post-test, using the same test instrument. The design of this study was in the form of a pretest posttest control group design.

The data collection in this study used a type of test instrument, namely a narrative writing ability test used in the initial and final tests. The questions are arranged in the form of a description test. The sample in this study was the fifth grade students of Elementary School in Aceh Besar.

\section{Types of research}

This research was conducted using experimental methods with qualitative and quantitative approaches. In this study, there were two sample groups, namely the experimental group learning to write narrative essays thematically through the use of mind mapping-based problem base learning methods (X_1) and the control group conducting ordinary learning (X_2). Both groups were given a pretest and posttest, using the same test instrument $(\mathrm{O})$. Because this research is an experimental study, the research design is in the form of Pre-test Post-test control group design

\section{Research Sample}

The sample in this study was class V Elementary School totaling 52 students consisting of two classes, namely class A (26 students) and (26 students). One class as an experimental class is a class that uses the problem base learning method based on mind mapping and the other class as a control class is a class whose learning is not given treatment.

\section{Research variable}

According to Arikunto (2012: 96) the variable is the object of research or the point of attention of a study. So, variables are everything that becomes the object to be studied in research. The variables used in this study are:

- The independent variable (free) is the problem base learning method based on mind mapping

- The dependent variable (bound) is the ability of students to write narrative essays.

\section{Data analysis technique}

The data analyzed is quantitative data in the form of narrative writing ability test results using a basic learning problem model with mind mapping. The statistical test used in this study is the average difference test with the following steps:

1. determine the score of the initial test and the final test of narrative writing skills using mind mapping-based problem-based learning for the experimental class and the control class.

2. determine the score for improving narrative writing skills using the normalized N-gain formula as introduced by Hake (in Mahmuzah, 2017), The results of the N-gain calculation are then interpreted using classification below: 
Table 1: Interval

\begin{tabular}{|c|c|}
\hline Interval & Category \\
\hline $\mathrm{g}>0,7$ & Very Good \\
\hline $0,3<\mathrm{g} \leq 0,7$ & Medium \\
\hline $\mathrm{g} \leq 0,3$ & Low \\
\hline
\end{tabular}

\section{Results and Discussions}

The results obtained from research conducted at SDN 1 Lambheu Aceh Besar, namely improving the ability to write narratives using the Problem Based Learning established with mind mapping method. In accordance with the data processing techniques that have been determined, the data will be processed based on predetermined criteria. Data processing using SPSS 16.0 with a significance level $=0.05$.

A total of 52 students involved in this study were divided into two different classes. A total of 26 students were in the experimental class, namely the class that received learning to write narrative essays using the problem base learning method based on mind mapping and 26 students were in the control class who received conventional learning.

Before using the difference test, the data obtained were tested for normality and homogeneity to determine the type of difference test to be used. This test was conducted to see the difference in students' ability to write narrative essays thematically between classes that received learning using the Mind mapping-based Problem base learning method (experimental class) and classes that received learning using a conventional approach. The results of data processing will be described as below.

Data on students' ability to write narrative essays before and after treatment were obtained through pre-test and post-test. The data to be analyzed in this study include the scores of the initial test, the final test and the N-gain of students' ability to write narrative essays in the experimental class taught using the Mind mapping-based Problem base learning method and the control class students taught with a conventional approach. The test used is in the form of a description. While the statistical description includes the average, standard deviation and the number of students based on the learning used are presented in the table below

Table 2. Test Results Ability to write narrative essays (using Mind mapping-based and Conventional Problem base learning methods

\begin{tabular}{|c|c|c|c|c|c|c|c|}
\hline Class & $\mathrm{N}$ & Test & $\begin{array}{l}\text { Max } \\
\text { Score }\end{array}$ & $\begin{array}{l}\text { Min } \\
\text { Score }\end{array}$ & $\bar{x}$ & SD & Var \\
\hline \multirow{2}{*}{ Experiment } & 26 & Pre-Test & 15 & 8 & 12.61 & 1.89 & 3.606 \\
\hline & & Post-Test & 19 & 12 & 16.80 & 2.03 & 4.162 \\
\hline \multirow[t]{2}{*}{ control } & 26 & Pre-Test & 16 & 9 & 12.92 & 1.67 & 2.794 \\
\hline & & Post_Test & 18 & 10 & 15.07 & 2.66 & 7.114 \\
\hline
\end{tabular}

Table 2 shows that the average score of students' initial ability to write narrative essays for the control class is higher than the experimental class. The average score of the initial ability to write narrative essays in the experimental class was 12.61 with a standard deviation of 1.89 , while the average score for the initial test in the control class was 12.92 with a standard deviation of 1.67. It can also be seen that the standard deviation of the control class is smaller than that of the experimental class, this indicates that the distribution of narrative writing ability in the control class is more varied than the experimental class. For the final test score, it can be seen that the average narrative writing ability of the experimental class is higher than the average. control class average. The standard deviation of the experimental class is 
higher than the control class. That is, the ability to write narrative essays in the experimental class is more spread out than control class.

\section{Similarity Test Average Initial Test of Students' Ability to Write Narrative Essay}

The average similarity test was carried out to see whether there was a difference in the average ability of students to write narrative essays before the treatment was given. Before the average similarity test is carried out, first the normality and homogeneity test of the data from the initial test results will be carried out in the experimental class and control class. Normality test using kolmogorov-smirnov (a). This test uses SPSS 16.0 with a significance level of 0.05. The test criteria are: Reject if Sig $\alpha .<=0.05$. With the formulation of the hypothesis can be classification into normally distributed data and not normally distributed data.

Tabel 3. Normal Test

\begin{tabular}{lcccr}
\hline & \multicolumn{3}{c}{ Kolmogorov-Smirnov ${ }^{\mathrm{a}}$} \\
\hline & Statistic & df & Sig. \\
\hline Pretest_Experiment & .157 & 26 & .098 \\
\hline Pretest_Control & .137 & 26 & .200 \\
\hline
\end{tabular}

Sign value. The experimental class and control class $>0.05$, namely 0.200 for the control class and 0.098 for the experimental class, so that the distribution of data for the two classes is normally distributed. Because the initial test data for writing narrative essays for the two classes followed a normal distribution, then the homogeneity test of the two initial test data was carried out. Homogeneity test (Levene's test) was conducted to determine whether the initial test data of the two classes were homogeneously distributed. Calculations using SPSS 17.0 with a significance level of 0.05 (. The test criteria is "if $\operatorname{Sig} \alpha .<=0.05$ then it is rejected". The formulation of the hypothesis is:

$\mathrm{H}_{0}$ : Both variances are homogeneous $\left(\sigma_{1}=\sigma_{2}\right)$

$\mathrm{H}_{1}$ : Both variances are not homogeneous $\left(\sigma_{1} \neq \sigma_{2}\right)$

Table 4. Homogeneity Test

\begin{tabular}{rccc}
\hline $\begin{array}{c}\text { Levene } \\
\text { Statistic }\end{array}$ & df1 & df2 & Sig. \\
\hline .482 & 1 & 50 & .491 \\
\hline
\end{tabular}

The results of the second homogeneity test output from the experimental class and control class obtained a sig value. $=0.491$ means the value of Sig $=0.491>0.05$ so it is accepted and it can be concluded that the two data are homogeneously distributed

Furthermore, the average similarity test was carried out on the two initial test data of students' ability to write narrative essays. Both data are normally distributed and homogeneously distributed, the test will use the t test. The analysis used SPSS 16.0 with a significance level of $\alpha=0,05$. The test criteria are: Reject if the value of sig. $<\alpha$.

The formulation of the hypothesis is:

$\mathrm{H}_{\mathrm{o}}$ : There is no difference in the ability to write narrative essays between experimental class students and control class students before treatment.

$\mathrm{H}_{\mathrm{I}}$ : There are differences in the ability to write narrative essays between experimental class students and control class students before treatment. 
The results of the $\mathrm{t}$ test can be seen in the table below

Table 5. Average Differences Test

\begin{tabular}{|c|c|c|c|c|c|c|}
\hline & & \multicolumn{2}{|c|}{$\begin{array}{c}\text { Levene's Test for } \\
\text { Equality of } \\
\text { Variances } \\
\end{array}$} & \multicolumn{3}{|c|}{ t-test for Equality of Means } \\
\hline & & $\mathrm{F}$ & Sig. & $\mathrm{t}$ & df & Sig. (2-tailed) \\
\hline \multirow[t]{2}{*}{ Pretest_Mixture } & $\begin{array}{c}\text { Equal } \\
\text { variances } \\
\text { assumed }\end{array}$ & .482 & .491 & .620 & 50 & .538 \\
\hline & $\begin{array}{c}\text { Equal } \\
\text { variances } \\
\text { not } \\
\text { assumed }\end{array}$ & & & .620 & 49.207 & .538 \\
\hline
\end{tabular}

Based on Table 4, the value of Sig. (2-tailed) $=0.538$ for the value of variance is not homogeneous $\mathrm{H}_{0}$ (Equal variances not assumed). Value of Sig. (2-tailed) $=0.538>0.05$ as a result, there is acceptance which means that "There is no difference in the ability to write narrative essays between experimental class students and control class students before treatment". Based on the results of the hypothesis test above, it can be concluded that before being given the treatment the ability to write narrative essays was the same for both classes.

\section{Normality and Homogeneity Test Average N-gain Students' Ability to Write Narrative Essay}

Normalized gain ( $\mathrm{N}$-gain) is an index of improving learning outcomes (Index of increasing students' ability to write narrative essays). Before testing the mean difference, first, normality and homogeneity tests were performed on the $\mathrm{N}$-gain to determine the statistical test used in hypothesis testing.

The following are the results of the descriptive analysis of the $\mathrm{N}$-gain ability to write narrative essays in the experimental class and control class.

Table 5. Description of Data N - Student Ability to gain Writing narrative essay

\begin{tabular}{|c|c|c|c|c|c|c|}
\hline & $\mathrm{N}$ & Minimum & Maximum & Mean & $\begin{array}{c}\text { Std. } \\
\text { Deviation }\end{array}$ & Variance \\
\hline $\begin{array}{l}\text { Ngain_Eksperime } \\
\mathrm{n}\end{array}$ & 26 & 12.00 & 19.00 & 16.8077 & 2.03998 & 4.162 \\
\hline Ngain_control & 26 & 10.00 & 18.00 & 15.0769 & 2.66718 & 7.114 \\
\hline Valid N (listwise) & 26 & & & & & \\
\hline
\end{tabular}

Based on the description of the data in table 5 that the average $\mathrm{N}$-gain ability of students to write narrative essays in the experimental class is greater than the control class. The standard deviation of the experimental class is higher than the control class. This means that the Ngain ability of the experimental class is more spread out than the control class.

Furthermore, the N-gain data normality test will be carried out on the students' ability to write 
narrative essays. This test uses SPSS 16.0 with a significance level. The test criteria are: "Reject if Sig $<=0.05$ ". With the formulation of the hypothesis:

$\mathrm{H}_{\mathrm{o}}$ : Data is normally distributed

$\mathrm{H}_{1}$ : Data is not normally distributed

The results of the normality test for the two $\mathrm{N}$-gain data are presented in the following table:

Table 6. N-gain Normality Test Results of Students' Ability to Write Narrative Essay

\begin{tabular}{lrrrr}
\hline & & & Kolmogorov-Smirnov $^{\mathrm{a}}$ & \\
& Statistic & Df & Sig. & .200 \\
\hline Ngain_Experiment & .131 & 26 & .200 \\
\hline Ngain_Control & .132 & 26 & \\
\hline
\end{tabular}

The sign value of the two classes $>0.05$ is 0.200 for both the experimental class and the control class so that the distribution of the data for the two classes is normally distributed. Since the data distribution of the two classes is normally distributed, the homogeneity of variance test and the mean difference test can be performed using a parametric test, namely the free sample $t$ test

Table 7. Varians Homogeneity Test

\begin{tabular}{crrrrr}
\hline $\begin{array}{l}\text { Levene } \\
\text { Statistic }\end{array}$ & \multicolumn{1}{c}{} & & & \\
df1 & df2 & Sig. & \\
\hline .007 & 1 & 50 & & .933 \\
\hline
\end{tabular}

The variance of the two classes is homogeneous because the sign value $>0.05$ is 0.933

Test the Difference in Average $\mathbf{N}$-gain of Students' Ability to Write Narrative Essays Based on Overall Students

The data distribution of the two classes is normally distributed, it can be tested for homogeneity of variance and the average difference test is carried out using a parametric test, namely the free sample t-test.

Table 8. Average Varian Test

\begin{tabular}{|c|c|c|c|c|c|c|c|}
\hline & & \multicolumn{2}{|c|}{$\begin{array}{c}\text { Levene's Test for } \\
\text { Equality of Variances }\end{array}$} & \multicolumn{4}{|c|}{ t-test for Equality of Means } \\
\hline & & $\mathrm{F}$ & Sig. & $\mathrm{t}$ & $\mathrm{df}$ & & $\begin{array}{l}\text { Sig. (2- } \\
\text { tailed) }\end{array}$ \\
\hline Pretest_Mixture & $\begin{array}{l}\text { Equal } \\
\text { variances } \\
\text { assumed }\end{array}$ & .007 & .933 & 3.638 & & 50 & .001 \\
\hline
\end{tabular}


Table 8. Average Varian Test

\begin{tabular}{|c|c|c|c|c|c|c|}
\hline & & \multicolumn{2}{|c|}{$\begin{array}{c}\text { Levene's Test for } \\
\text { Equality of Variances }\end{array}$} & \multicolumn{3}{|c|}{ t-test for Equality of Means } \\
\hline & & $\mathrm{F}$ & Sig. & $\mathrm{t}$ & df & $\begin{array}{l}\text { Sig. (2- } \\
\text { tailed) }\end{array}$ \\
\hline \multirow[t]{2}{*}{ Pretest_Mixture } & $\begin{array}{l}\text { Equal } \\
\text { variances } \\
\text { assumed }\end{array}$ & .007 & .933 & 3.638 & 50 & .001 \\
\hline & $\begin{array}{l}\text { Equal } \\
\text { variances not } \\
\text { assumed }\end{array}$ & & & 3.638 & 49.950 & .001 \\
\hline
\end{tabular}

The results of the t-test indicate that there is a difference in the average value of the experimental class and the control class because the sign value $<0.05$ is 0.001 . Based on the test criteria "Reject if Sig. $<0.05$ ". This results in acceptance. So it can be concluded that the improvement in the ability of students to write narrative essays thematically who received learning using the problem base learning method based on mind mapping was better than students who received learning to write conventional thematic narrative essays as a whole. This shows that good media are able to achieve learning objectives efficiently. (Akbar, 2013) media that is capable of achieving high learning objectives means that the media is effective. The right learning model or media can also increase learning effectiveness, motivation, enthusiasm for learning and students' interest in learning in class (Sohibun \& Ade. 2017)

Based on the results of the research above, creative thinking in writing narratives can be optimized using the Problem base learning method based on mind mapping. Mind mapping which means a mind map, utilizing and focusing the whole brain to think creatively so as to create high imagination power (Swadarma, 2013) considering that mastery of writing skills is very important to express ideas, ideas, thoughts in written form and is useful for students to take notes, work on school assignments (Musyawir \& Loilatu, 2020; Mardhatillah \& Akmalia, 2017).

Data on students' writing skills before and after treatment were obtained through a pretest (pretest) and a final test (posttest). The data to be analyzed in this study include the scores of pretest, posttest and n-gain narrative ability of experimental class students who are taught using mind mapping-based problem-based learning (PBL) and control class students who are taught using a conventional approach. The test used is in the form of a description. While the statistical description includes the average, standard deviation and the number of students based on learning

The analysis of the students' ability to relate material between subjects, the average pretest score of the experimental class students (12.61) and the average pretest of the control class students (12.92), showed that the control class students' ability to relate material between subjects in writing narrative essays was better than that of the control class. After being given treatment in the form of serial image media in the experimental class, the posttest average value (16.80), meaning that it has increased. Meanwhile, the average score for the control class was (15.07). It can be seen that the experimental class has better ability to connect between subjects than the control class. However, the overall ability of students to relate material between subjects is still very lacking. This can be caused by the fact that students are not used to writing thematically. Students are still used to thinking partially.

The importance of the ability to link between subjects is expressed by Rusman (2012: 
258) by mentioning the benefits of thematic learning, including the following: combining several basic competencies and indicators and subject matter content will result in savings, because overlapping material can be reduced or even eliminated; Students can see meaningful relationships because the content / learning material acts more as a tool or tool; Learning is not fragmented because students are equipped with a more integrated learning experience so that they will get a more integrated understanding of the process and material as well; Provide applications from the real world so as to enhance the opportunity for transfer of learning (transfer of learning); With the integration between subjects, the mastery of learning materials will be better and increase. So, learning with a thematic approach can contribute to improving students' ability to relate the connectedness of all the subjects being studied. Thus, making it easier for students to learn, especially writing skills.

\section{Conclusions}

Based on the results of the data analysis that has been presented in the previous chapter, it can be concluded that the improvement of thematic narrative writing skills of students who received learning using a mind mapping-based problem-based learning model is better than students who received the conventional learning. The problem-based learning method facilitated the students to develop themes holistically.

Mind mapping-based problem-based learning models are considered effective in improving students' ability to write narratives thematically. This can be seen from the difference in the average pretest score of students in the experimental group of 12.61 and the posttest score increased to 16.80 .

\section{Acknowledgments}

The author would like to thank RISTEKDIKTI for providing financial support for this study.

\section{References}

Akbar, S. (2013). Instrumen Perangkat Pembelajaran. Bandung: Rosdakarya. Arikunto, S. (2012). Dasar-dasar Evaluasi Pendidikan Edisi 2. Jakarta: Aksara.

Cahyani, I. (2019). Model Pembelajaran Problem Based Learning dalam Menulis Narasi. Seminar internasional riksa bahasa XIII. http://prosedings.edu/index.php/riksabahasa

Mahmuzah, R., and Aklimawati. (2017). Peningkatan Kemampuan Penalaran Matematis Siswa SMP Melalui Pendekatan Problem Posing. Jurnal Numeracy, 4 (2), 71-78

Mardhatillah, M., \& Akmalia, N. (2017). Upaya Meningkatkan KemampuanMenulis Karangan Melalui MetodeImage Streaming Dengan Media Gambar Seri. Rekognisi: Jurnal Pendidikan dan Kependidikan, 2(2).

Mirnawati, L K. (2020). Proses Pengembangan Model Pembelajaran Inovatif dengan Menggunakan Mind Mapping dalam Pembelajaran Menulis Narasi di SD. Proceding. Literasi Dalam Pendidikan di Era Digital Untuk Generasi Milenial.

Mulyasa. (2013). Pengembangan dan implementasi Kurikulum 2013. Bandung:PT Remaja Rosdakarya.

Musyawir., and Loilatu, S.H. (2020). Kemampuan Menulis Karangan Narasi Berdasarkan Pengalaman Pribadi Siswa. Uniqbu Journal of Social Science (UJSS), 1(2).

Rusman. (2012). Model-Model Pembelajaran [Learning models]. Jakarta: PT Raja Grafindo Persada.

Sohibun, \& Ade, F.Y. (2017). Pengembangan Media Pembelajaran Berbasis Virtual Class Berbantuan Google Drive. Tadris : Jurnal Keguruan Dan Ilmu Keguruan, 2(2), 121129. 
Swadarma, D. (2013). Penerapan Mind Mapping dalam Kurikulum Pembelajaran. Jakarta:PT Elex Media Komputindo

Tarigan, H.G. (2008) Menulis [Writing]. Bandung: Angkasa. 